\title{
Leaf structural and physiological factors for winter dormancy color of zoysiagrass (Zoysia spp. Willd.)
}

\author{
Lijuan Xie ${ }^{1}$, Huisen $\mathrm{Zhu}^{2}$, Huimin $\mathrm{Guo}^{2}$ and Deying $\mathrm{Li}^{3}$ \\ ${ }^{1}$ School of Applied Chemistry and Biotechnology, Shenzhen Polytechnic, Shenzhen, China \\ ${ }^{2}$ College of Grassland Science, Shanxi Agricultural University, Taigu, Shanxi, China \\ ${ }^{3}$ Department of Plant Sciences, North Dakota State University, Fargo, ND, U.S.A.
}

\section{Summary}

Zoysiagrass is increasingly used on golf courses and athletic fields in regions with a warm climate because of high heat and drought tolerance and low maintenance cost. Despite the stronger winter-hardiness comparing to other warm-season grasses, it has a relatively shorter green period than cool-season grasses. Therefore, zoysiagrass cultivars with a greater brightness as in the hue-saturation-brightness system during the dormancy are more desirable for winter use if not overseeded or dyed. The objective of this experiment was to determine factors that are important for winter dormancy color of zoysiagrass. Materials tested were two commercial cultivars and nine wild accessions from $31^{\circ} 1^{\prime} \mathrm{N}$ to $41^{\circ} 11^{\prime} \mathrm{N}$ in China. Plants were maintained in growth chambers and freezers that have temperatures, photoperiods, and light intensity controlled to simulate growth conditions in fall and winter. Grass color was analyzed based on the CIELAB color space. During the dormancy period, all accessions lost green color (the greento-red scale, $a^{*}$, became more positive). The levels of yellow perception were significantly different among the accessions and cultivars as indicated by the blueto-yellow scale $\left(b^{*}\right)$ (5.75 to 12.75$)$. The leaf brightness during this stage was also significantly different among the accessions with brightness $\left(L^{*}\right)$ ranging from 41.75 to 50.75 . Trichome density showed no effects on dormancy color or brightness. Despite the fact that accessions from lower latitudes were waxier, increasing waxiness in winter-hardy materials also increased dormancy color brightness. Both carotenoid and total flavonoids contribute to yellow color. More research should be conducted on specific yellow flavonoids and their genetics and metabolism in zoysiagrass.

Keywords

aesthetics, color retention, dormant, low temperature, turfgrass

\section{Introduction}

Zoysiagrass is a warm-season plant species originated from East Asia (Christians et al., 2017). Because of its strong tolerance to drought, close mowing, and excellent verdure elasticity and resiliency, zoysiagrass is increasingly used on golf courses and athletic fields in the transition zone with a warm climate (Fry et al., 2008; Patton et al., 2017; Magni et

\section{Significance of this study}

What is already known on this subject?

- Dormant zoysiagrasses have different hue and brightness, and attractiveness.

What are the new findings?

- Leaf epicuticle wax but not trichome affects zoysiagrass dormancy color brightness.

- Carotenoid contributes to yellow color but not correlated with dormancy differences.

- Accessions had various flavonoids levels which were correlated with levels of yellow.

What is the expected impact on horticulture?

- Leaf specific yellow flavonoids, as well as epicuticular wax and trichome traits in zoysiagrass could be used to improve its winter dormancy color.

al., 2017). The strongest driving force for its wide use is likely the water conservation (Watson, 1989).

Zoysiagrass has its own limitations as a turfgrass species. One of the most is the relatively shorter green period and weaker winter-hardiness as compared to cool-season grasses. Zoysiagrass requires a minimum temperature of $21^{\circ} \mathrm{C}$ to have noticeable growth (Youngner, 1961). As daylength shortens and temperatures decrease in fall, zoysiagrass slows down its growth. It goes dormant when the daily average temperature is below $15^{\circ} \mathrm{C}$ and the daily minimum temperature is below $10^{\circ} \mathrm{C}$ (Nakamura and Nakamae, 1984). The dormancy color of zoysiagrass is golden-tan. Very often, a zoysiagrass facility is not immediately closed as the grass goes into winter dormancy, especially on golf courses and sports fields where the turfgrass cover is still functional, to meet the needs of customers and to increase revenue. Some facilities seed into a dormant zoysiagrass with a cool-season species with green winter color (overseeding) (Hurley et al., 1989; Gibeault et al., 1997). Some facilities spray green colorants on dormant zoysiagrass to enhance the color intensity and continue to operate (Braun et al., 2017).

Turfgrass breeders made it one of the top priorities to select cold-tolerant cultivars of zoysiagrass with longer green period (Brilman, 2005; Okeyo et al., 2011). However, to combine fine leaf texture and cold tolerance as well as other important traits, such as seed yield and pest resistance in one cultivar, is a very slow and challenging process (Engelke and Murray, 1989; Guo et al., 2012). The vegetative cultivar 'Meyer' was released in 1952 (Grau and Radko, 1951) and is still a benchmark for newer cultivars, especially in the tran- 
sition zone of the United States. 'Ultimate', released in 2012, is an improvement in leaf texture and vegetative propagation speed but no more winter-hardy than 'Meyer' (Scully et al., 2012). 'Chisholm', released in 2014, has improvement on vegetative propagation speed but is inferior to 'Meyer' in texture and cold tolerance (Chandra et al., 2015). 'Zenith', a seeded cultivar, was reported to have similar cold tolerance but wider leaf blade than 'Meyer' (Patton and Reicher, 2007; Patton et al., 2017). However, a two-year trial conducted in Europe showed that 'Zenith' did not perform better than 'Meyer' in terms of green period (Pompeiano et al., 2014). 'Innovation', released in 2017, is an improvement on 'Meyer' in terms of leaf texture and general turfgrass quality, but needs to propagate vegetatively (Chandra et al., 2017). Customers prefer a zoysiagrass cultivar with greater brightness, and hue of green or golden yellow if without overseeding or dyeing (Braun et al., 2017). In addition to brightness, the tint, shade, and tone of a dormant turfgrass color also affect human perceptions. Home lawns and other amenity turf are considered more attractive when the dormant color is brighter (Kuper, 2015). Therefore, an alternative or additional strategy zoysiagrass breeders can adopt is to breed cultivars with an attractive hue and greater brightness in dormancy.

The hue of leaf color and brightness of grasses during growth are primarily determined by the concentrations of chlorophyll and other pigments, leaf surface pubescence, and epicuticle wax in the growing season (Barthlott et al., 2017). As temperature drops, zoysiagrass leaves initiate senescence and go through metabolic changes. The speed of senescence is dependent on weather conditions as well as plant health status. In warm regions, green color sustains longer and sometimes stays green over the winter, so-called "evergreen" (Akamine et al., 2001). Cultural practices also influence the speed of senescence, especially that of nitrogen and iron fertilization management (Gibeault et al., 1997; Pompeiano et al., 2011). During leaf senescence, chlorophylls are metabolized and different pigments are formed. Some of these pigments, such as phyllobilins (Li et al., 2016), bilirubin (Lightner, 2013), and phytochromobilin (Falk, 1989), are responsible for yellow color, while flavonoids (anthocyanidins, flavan-3-ols, flavonols, flavones, flavanones, and isoflavones) for red, yellow or purple coloring (Kumar and Pandey, 2013). In the meanwhile, the colors of ubiquitous beta-carotene and xanthophylls begin to reveal from the chlorophyll mask and show yellow, orange, or red colors because of chlo- rophyll degradation (Hortensteiner, 2006). Pompeiano et al. (2015) reported that zoysiagrass chlorophyll content, photosynthetic capacity, and carbohydrate reserves change in a synchronized process with the color progression during the senescence, dormancy, and green up.

Leaf structure also affects its color as perceived by humans. The structural effects on color perception can happen at macro scale and nanoscale. At macro scale, it is well recognized that brightness and hue of leaf color are affected by trichome (Ehleringer and Bjorkman, 1978; Ntefidou and Manetas, 1996; Mershon et al., 2015) and epicuticular wax (Sanchez et al., 2001; Esteban et al., 2014; Guimaraes et al., 2014). At nanoscale, the leaf structural effect on color is referred to as structural color, which is not contributed from pigments. Structural color is the result of differential reflection of particular wavelengths by multilayer reflectors in the leaf tissue and the result of surface diffraction gratings by ordered nanoscale patterns of cells in the leaf tissue (Tripathy et al., 2014; Moyroud et al., 2017; Airoldi et al., 2019).

The objective of this study was to investigate factors that determine winter dormancy color of zoysiagrass. In particular, we were interested in the effects of leaf surface structure, pigments, and major metabolites prior to and during the winter dormancy on canopy color of zoysiagrass germplasm. We expected to identify important traits for breeding cultivars with better dormancy color. Additionally, information on the mechanisms influencing winter dormancy color of zoysiagrass can help turfgrass managers to make science-based decisions in management practices.

\section{Materials and methods}

Eleven collections of zoysiagrass were used in this experiment. Six wild accessions and two cultivars ('Meyer' and 'Zenith') were Z. japonica Steud., wild accession was Z. pacifica Goudsw. (previously known as Z. tenuifolia Willd. ex Thiele), and one wild accession was Z. matrella (L.) Merr. These wild accessions were selected because of the wide representation range of geological distribution from $31^{\circ} 1^{\prime} \mathrm{N}$ to $41^{\circ} 11^{\prime} \mathrm{N}$ in China (Table 1). Grasses were vegetatively propagated from sprigs in a glass house. Mature stands were transferred to plastic pots measuring $15 \mathrm{~cm}$ by $15 \mathrm{~cm}$ and $11 \mathrm{~cm}$ deep with a silt loam soil as growth medium (pH 7.6, OM 4.2\%). Grasses were maintained in a greenhouse at $30^{\circ} \mathrm{C} / 20^{\circ} \mathrm{C}$ (day/night), watered to field capacity every three days, and fertilized with half-strength Hoagland solution (Hothem et al., 2003) week-

TABLE 1. Commercial cultivars and natural accessions of Zoysia spp. Willd. from China used in the experiment to determine factors affecting winter dormancy color.

\begin{tabular}{llll}
\hline Species & Accession source & Longitude & Latitude \\
\hline Z. matrella & Shanghai & $121^{\circ} 26^{\prime} 25^{\prime \prime}$ & $31^{\circ} 1^{\prime} 10^{\prime \prime}$ \\
Z. pacifica & Jingzhou, Hubei & $112^{\circ} 11^{\prime} 26^{\prime \prime}$ & $32^{\circ} 10^{\prime} 28^{\prime \prime}$ \\
Z. japonica & Shanghai & $121^{\circ} 26^{\prime} 25^{\prime \prime}$ & $31^{\prime} 10^{\prime \prime}$ \\
Z. japonica & Jingzhou, Hubei & $112^{\circ} 11^{\prime} 26^{\prime \prime}$ & \\
Z. japonica 'Zenith' & U.S.A. & & \\
Z. japonica 'Meyer' & U.S.A. & & \\
Z. japonica & Shandong & $118^{\circ} 59^{\prime} 28^{\prime \prime}$ & $36^{\circ} 13^{\prime} 45^{\prime \prime}$ \\
Z. japonica & Liaoning & $123^{\circ} 11^{\prime} 49^{\prime \prime}$ & $40^{\circ} 4^{\prime} 26^{\prime \prime}$ \\
Z. japonica & Liaoning & $123^{\circ} 23^{\prime} 4 "$ & $40^{\circ} 25^{\prime} 24^{\prime \prime}$ \\
Z. japonica & Jilin & $126^{\circ} 8^{\prime} 6^{\prime \prime}$ & $41^{\circ} 7^{\prime} 38^{\prime \prime}$ \\
Z. japonica & Liaoning & $125^{\circ} 21^{\prime} 11^{\prime \prime}$ & $41^{\circ} 11^{\prime} 15^{\prime \prime}$ \\
\hline
\end{tabular}

t: also previously known as Z. tenuifolia. 
ly. The pots were maintained at this regime for two months before being transferred to growth chambers to initiate the fall and winter simulations.

Grasses were maintained in four growth chambers (RGX360BE, Lichen Technology, Shanghai, China) with three phases simulating fall conditions and then moved to four freezers for two phases simulating winter conditions. The top-accessing freezers (WD4-568, Suiling, Guangzhiu, China) had a sliding glass door for external lights. Phase 1 subjected grasses to $28^{\circ} \mathrm{C} / 20^{\circ} \mathrm{C}$ (day/night), $15 \mathrm{~h} / 9 \mathrm{~h}$ (light/dark) photoperiod, and a photosynthetically active radiation (PAR) of $300 \mu \mathrm{mol} \mathrm{m}{ }^{-2} \mathrm{~s}^{-1}$ for 4 weeks. In phase 2 , grasses were maintained at $20^{\circ} \mathrm{C} / 10^{\circ} \mathrm{C}$ (day/night), $12 \mathrm{~h} / 12 \mathrm{~h}$ (light/dark) photoperiod, and a PAR of $300 \mu \mathrm{mol} \mathrm{m}{ }^{-2} \mathrm{~s}^{-1}$ for 2 weeks. In phase 3 , grasses were exposed to $15^{\circ} \mathrm{C} / 5^{\circ} \mathrm{C}$ (day/night), $10 \mathrm{~h} / 14 \mathrm{~h}$ (light/dark) photoperiod, and a PAR of $200 \mu \mathrm{mol} \mathrm{m}{ }^{-2} \mathrm{~s}^{-1}$ for 2 weeks. In phase 4 , grasses were maintained at $5^{\circ} \mathrm{C} / 0^{\circ} \mathrm{C}$ (day/night), $10 \mathrm{~h} / 14 \mathrm{~h}$ (light/dark) photoperiod, and a PAR of $100 \mu \mathrm{mol} \mathrm{m}{ }^{-2} \mathrm{~s}^{-1}$ for 2 weeks. Grasses in phase 5 were maintained at $-5^{\circ} \mathrm{C}, 8 \mathrm{~h} / 16 \mathrm{~h}$ (light/dark) photoperiod, and a PAR of $100 \mu \mathrm{mol} \mathrm{m}^{-2} \mathrm{~s}^{-1}$ for 4 weeks. During phase 1 , plants were watered to field capacity every three days and fertilized with half-strength Hoagland solution weekly. During phase 2 and 3 , plants were watered to field capacity weekly, whereas no watering occurred in the remaining phases. The experiment was arranged in a randomized complete block design with four replicates with each replicate in a different growth chamber. The experiment was conducted once in 2018 and once in 2019.

Throughout data collection and analysis, phase 3 of the treatment was referred to as the phase prior to dormancy and phase 4 and 5 were referred to as the phase of dormancy. On the last day of phase 3 and 5, plant samples were taken for observation of leaf surface structure (trichomes and stomata), measurement of leaf pigments (chlorophyll, carotenoids, and total flavonoids), and analysis of leaf color. At the end of phase 5, leaf epicuticular wax was also measured. After phase 5, all pots were moved to a greenhouse under $30^{\circ} \mathrm{C} / 20^{\circ} \mathrm{C}$ (day/night) and watered weekly to allow for green-up. Four weeks later, survival rate was determined from the percentage of green-up shoots in the total shoots (dead and green-up shoots).

Three fully expanded leaves from each genotype in each replicate were randomly sampled for surface observation. The adaxial and abaxial surfaces were observed under a dissecting microscope (SZX2-ILLT, Olympus, Tokyo, Japan) for trichome density. Trichomes were counted in each field of view and recorded as number per unit area. Each field of view was also photographed for the record. A similar sampling scheme was used for stomata observation. A leaf sample was shaved with a razor blade while the leaf was submerged in a few drops of water on a glass slide to prepare the epidermal specimen. The epidermal specimen was observed under a light microscope (BX51TF, Olympus, Tokyo, Japan). The stomata density was counted for each field of view and recorded as number of stomata per unit area. Each field of view was also photographed for the record.

For the analysis of leaf color, 20 randomly selected leaves from each genotype of a replicate were cut off using scissors and arranged side-by-side without gaps on a piece of paper and secured with scotch tape on edges. The arranged leaf samples were then photographed using a digital camera under F1.8, exposure time $0.01 \mathrm{~s}$, and ISO 250. The images were then analyzed using the Image Color Summarizer $0.76^{\circ}$ (http://mkweb.bcgsc.ca) for the determination of parame- ters $\left(L^{*} a^{*} b^{*}\right)$ in the CIELAB color space, where $L^{*}$ is lightness from black to white (0 to 100), $a^{*}$ is from green to red ( -100 to 100$)$, and $b^{*}$ is from blue to yellow (-100 to 100$)$. The CIELAB color space was used because it is a good estimation of color perception by human eyes, and can be quantified (Kuehni, 2003).

For the measurement of leaf chlorophyll and carotenoid content, three 0.2-g fresh full-expanded leaf samples from each genotype in each replicate were collected. The sample was ground and washed with $2 \mathrm{~mL} 80 \%$ acetone into a centrifuge tube and capped for extraction under $-4^{\circ} \mathrm{C}$ for $24 \mathrm{~h}$. After extraction, the sample was centrifuged. The supernatant then was transferred and diluted to $25 \mathrm{~mL}$ with $80 \%$ acetone. The light absorbance by the extraction was measured at 663,646 and $470 \mathrm{~nm}$ using a spectrophotometer (UV9000-S, Metash Inc., Shanghai, China). The concentrations of chlorophyll and carotenoid were calculated from the absorbance values using the equation by Lichtenthaler (1987).

Fully expanded leaves were sampled from each genotype for flavonoid analysis. In a test tube containing $1 \mathrm{~g}$ of ground leaf sample, $50 \mathrm{~mL}$ of $60 \%$ methanol was added and treated with ultrasonic at $40 \mathrm{kHz}, 180 \mathrm{~W}$ for $30 \mathrm{~min}$ (SB3200D, Xinzhi Biotechnology Co. Ltd., China). The extraction was then centrifuged at $8,000 \mathrm{~g}$ for $20 \mathrm{~min}$. The supernatant was analyzed using a Breeze ${ }^{\mathrm{TM}}-2$ HPLC equipped with a Water1500 pump and a model 2489 UV detector (Waters Corporation, Milford, MA, U.S.A.). The column for the HPLC was a Waters XBridge C18 (150 mm × $4.6 \mathrm{~mm}, 5 \mu \mathrm{m}$ ) (Waters Corporation, Milford, MA, U.S.A.) and was controlled at $30^{\circ} \mathrm{C}$. The sample injection volume was $10 \mu \mathrm{L}$. The mobile phase was a mixture of $95 \mathrm{~mL}$ acetonitrile and $5 \mathrm{~mL} 0.4 \%$ methanoic acid, and was controlled at flow rate of $0.5 \mathrm{~mL} \mathrm{~min}^{-1}$. The detector wavelength was $360 \mathrm{~nm}$.

For leaf epicuticular wax determination we followed the method by Daly (1963) with minor modification; $1 \mathrm{~g}$ of fully expanded leaves was sampled from each accession. The leaves were scanned for surface area determination before put in a pre-dried and pre-weighed $\left(\mathrm{W}_{1}\right)$ evaporation glass dish. To each dish, $20 \mathrm{~mL}$ of chloroform was added to soak the leaves for $30 \mathrm{~s}$ before removing the leaves. The chloroform in the dish was allowed to evaporate in a laboratory fume hood under room temperature. The dishes were then moved to a glass desiccator to dry for $24 \mathrm{~h}$ before being weighed again $\left(W_{2}\right)$. The weight difference $\left(W_{2}-W_{1}\right)$ of a dish was considered as wax weight. Leaf area was determined from the digital image using an Image software (National Institutes of Health, U.S.A.). The wax load was reported as weight per unit leaf area.

Data normality was tested and the two experimental runs were combined and were analyzed using the mixed model for the analysis of variance in SAS (SAS Institute, North Carolina, U.S.A.). The treatment means were separated using Tukey's least significant difference when $F$-test was significant at the 0.05 probability level. Simple correlations were calculated using the CORREL function in Excel (Microsoft Office 2016) and the correlation coefficients were subjected to $T$-test.

\section{Results and discussion}

\section{Dormancy color and low-temperature tolerance}

The levels of leaf green color prior to dormancy (phase 3) were different among the accessions with a more negative value of $a^{*}$ indicating more green (Table 2). 'Zenith' and accessions from further south in China $\left(<36^{\circ} \mathrm{N}\right)$ (Table 1) were generally greener (with $a^{*}<-6.25$ and $b^{*}>25$ ) than accessions 
TABLE 2. Winter survival and dormancy color of two commercial cultivars and nine wild accessions of Zoysia spp. Willd. with perception of color expressed in the CIELAB color space.

\begin{tabular}{|c|c|c|c|c|c|c|c|c|}
\hline \multirow{3}{*}{ Species } & \multirow{3}{*}{ Accession source } & \multicolumn{6}{|c|}{ CIELAB color space ${ }^{\ddagger}$} & \multirow{3}{*}{$\begin{array}{c}\text { Survival } \\
\text { rate } \\
\%\end{array}$} \\
\hline & & \multicolumn{3}{|c|}{ Prior to dormancy } & \multicolumn{3}{|c|}{ Dormancy } & \\
\hline & & $a^{*}$ & $b^{*}$ & $L^{*}$ & $a^{*}$ & $b^{*}$ & $L^{*}$ & \\
\hline Z. matrella & Shanghai & $-6.25 c$ & 25.50 & 77.25 & $0.00 f$ & $8.25 \mathrm{~cd}$ & 42.75ef & $0 c$ \\
\hline Z. pacifica ${ }^{\dagger}$ & Jingzhou, Hubei & $-9.25 e$ & 25.50 & 78.25 & $3.25 \mathrm{cde}$ & $8.50 \mathrm{~cd}$ & $45.25 d$ & $0 c$ \\
\hline Z. japonica & Shanghai & $-6.50 c$ & 27.00 & 72.25 & $4.00 \mathrm{bcd}$ & $8.50 \mathrm{~cd}$ & $41.75 f$ & $50 c$ \\
\hline Z. japonica & Jingzhou, Hubei & $-7.75 d$ & 27.00 & 77.50 & $2.25 \mathrm{def}$ & $8.00 \mathrm{~cd}$ & $43.50 \mathrm{e}$ & $90 \mathrm{~b}$ \\
\hline Z. japonica 'Zenith' & U.S.A. & $-6.25 c$ & 27.00 & 74.50 & 0.75 ef & $9.75 b c$ & $46.75 c$ & $95 b$ \\
\hline Z. japonica 'Meyer' & U.S.A. & $-5.00 b$ & 26.00 & 72.50 & $5.00 \mathrm{abc}$ & $5.75 e$ & $42.00 f$ & $100 a$ \\
\hline Z. japonica & Shandong & $-4.50 b$ & 26.75 & 73.50 & $3.00 \mathrm{cde}$ & $7.00 \mathrm{de}$ & $46.75 \mathrm{c}$ & $100 a$ \\
\hline Z. japonica & Liaoning & $-4.00 a b$ & 29.75 & 76.75 & $6.25 a b$ & $8.25 \mathrm{~cd}$ & $45.75 d$ & $100 a$ \\
\hline Z. japonica & Liaoning & $-3.75 a b$ & 29.00 & 71.00 & $5.00 \mathrm{abc}$ & $11.75 a b$ & $49.25 b$ & $100 a$ \\
\hline Z. japonica & Jilin & $-4.00 a b$ & 29.00 & 76.75 & $6.75 a$ & $11.75 a b$ & $50.50 a$ & $100 a$ \\
\hline Z. japonica & Liaoning & $-3.00 a$ & 28.25 & 76.00 & $4.25 \mathrm{abcd}$ & $12.75 a$ & $50.75 a$ & $100 a$ \\
\hline
\end{tabular}

t: also previously known as Z. tenuifolia.

‡: $a^{*}$ values range from -100 (greenish) to 100 (reddish), $b^{*}$ values range from -100 (blueish) to 100 (yellowish), and $L^{*}$ represents lightness ranging from 0 (black) to 100 (white) in the CIELAB color space.

from further north at this stage (Table 2). The degree of yellowish and brightness were not different among the cultivar and accessions at this stage $\left(b^{*}=25.5\right.$ to $29, L^{*}=71$ to 78.25$)$ (Table 2). The accessions that were greener prior to dormancy had lower survival rate $(<90 \%)$ under low-temperature conditions during dormancy (Table 2). This may partially be explained by the lack of acclimation to low temperatures in the accessions from lower latitudes, which failed to sense the shortening day length and/or decreasing temperatures and maintained the green color. Acclimation plays an important role for winter-hardiness in many plants. Both proteins and carbohydrates are responsible for low temperature acclimation in zoysiagrass (Patton et al., 2007a, b; Brown et al., 2020). Successful acclimation is not achieved equally by all accessions under same environmental conditions because zoysiagrasses vary in their ability to sense the changing environments and accomplish the acclimation process (Dunn, 1999; Pompeiano et al., 2011; Hinton et al., 2012).
During dormancy (phase 5), all grasses lost green color ( $a^{*}$ values became more positive) and became more yellow (Table 2, Figure 1). Although there were differences among accessions in $a^{*}$, the effect was not in the green area but more toward red. The levels of yellow perception were different among the accessions and cultivars as indicated by the $b^{*}$ values (5.75 to 12.75 ) (Table 2). A higher positive $b^{*}$ value indicates more yellow (Figure 1). The leaf brightness during this stage was different among the accessions too $\left(L^{*}=41.75\right.$ to 50.75) (Table 2). These values are similar to the range reported by Fukuyama et al. (1993) for zoysiagrass leaf color in later fall. In comparison, larger changes in $a^{*}$ than in $b^{*}$ and $L^{*}$ of the CIELAB color space were observed during fall temperature changes in zoysiagrass accessions (Fukuyama et al., 1993).

The $b^{*}$ value for 'Zenith' (9.75) was higher than that of 'Meyer' (5.75). 'Zenith' was slightly brighter $\left(L^{*}=46.75\right)$ than 'Meyer' $\left(L^{*}=42\right)$. The results showed that the perception

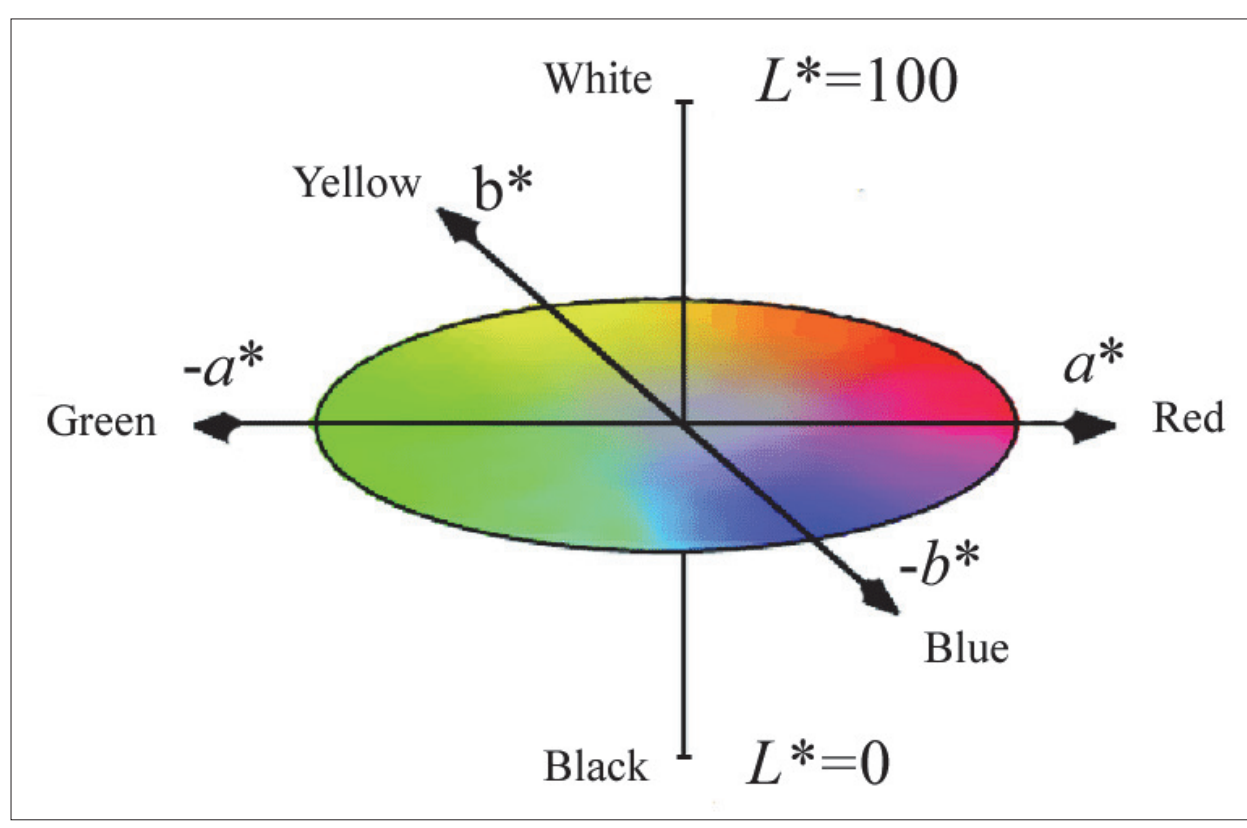

FIGURE 1. Illustrations of a CIELAB color space showing relations of $a^{*}, b^{*}$ and $L^{*}$. 
TABLE 3. Leaf surface structure of two commercial cultivars and nine wild accessions of Zoysia spp. Willd. from China during low temperature dormancy.

\begin{tabular}{lllccc}
\hline & & \multicolumn{2}{c}{ Trichome density } & \multicolumn{2}{c}{ Stomate density } \\
\cline { 3 - 5 } Species & Accession source & Adaxil & Abaxil & Adaxil & Abaxil \\
\cline { 3 - 5 } & & & \multicolumn{2}{c}{ Count mm ${ }^{-2}$} \\
\hline Z. matrella & Shanghai & $0.353 \mathrm{~cd}$ & $0.144 \mathrm{c}$ & $136.0 \mathrm{bc}$ & $81.7 \mathrm{~d}$ \\
Z. pacifica & Jingzhou, Hubei & $0.083 \mathrm{~d}$ & $0.124 \mathrm{c}$ & $168.3 \mathrm{ab}$ & $93.7 \mathrm{bcd}$ \\
Z. japonica & Shanghai & $0.131 \mathrm{~d}$ & $0.080 \mathrm{c}$ & $174.8 \mathrm{a}$ & $110.5 \mathrm{abc}$ \\
Z. japonica & Jingzhou, Hubei & $0.178 \mathrm{~d}$ & $0.000 \mathrm{c}$ & $175.8 \mathrm{a}$ & $84.6 \mathrm{dc}$ \\
Z. japonica 'Zenith' & U.S.A. & $0.381 \mathrm{~cd}$ & $0.134 \mathrm{c}$ & $132.9 \mathrm{c}$ & $80.1 \mathrm{~d}$ \\
Z. japonica 'Meyer' & U.S.A. & $1.120 \mathrm{a}$ & $1.992 \mathrm{~b}$ & $168.2 \mathrm{ab}$ & $123.1 \mathrm{a}$ \\
Z. japonica & Shandong & $0.267 \mathrm{~d}$ & $0.236 \mathrm{c}$ & $134.0 \mathrm{c}$ & $84.9 \mathrm{dc}$ \\
Z. japonica & Liaoning & $0.467 \mathrm{~cd}$ & $0.397 \mathrm{c}$ & $162.7 \mathrm{abc}$ & $119.4 \mathrm{ab}$ \\
Z. japonica & Liaoning & $0.691 \mathrm{bc}$ & $0.543 \mathrm{c}$ & $170.7 \mathrm{abc}$ & $130.5 \mathrm{a}$ \\
Z. japonica & Jilin & $0.888 \mathrm{ab}$ & $0.314 \mathrm{c}$ & $155.3 \mathrm{abc}$ & $119.9 \mathrm{ab}$ \\
Z. japonica & Liaoning & $1.249 \mathrm{a}$ & $3.406 \mathrm{a}$ & $161.2 \mathrm{abc}$ & $106.4 \mathrm{abcd}$ \\
\hline
\end{tabular}

†: also previously known as Z. tenuifolia.

that 'Zenith' has a brighter yellow color than 'Meyer' during winter dormancy is verified by these values. In this aspect, three accessions collected from the higher latitudes $\left(>40^{\circ} \mathrm{N}\right)$ showed a brighter yellow color than 'Zenith' (Table 2), which is worth further exploration in breeding efforts.

\section{Leaf surface structure}

Cultivars and accessions tested in this experiment showed differences in stomata density both on the adaxial and abaxial side of the leaves. However, there were no obvious trends in stomata density with respect to the latitudes of collection (Table 3). Therefore, this trait should be investigated in relation to stress tolerances and photosynthetic capacity. Previous research indicated that higher stomatal density was positively correlated with leaf rust tolerance in zoysiagrass (Li et al., 2018). The photosynthetic $\mathrm{O}_{2}$ evolution under low temperatures was not associated with geological locations of zoysiagrass with different stomata density (Okawara and Kaneko, 1997).
The accessions from higher latitudes were generally more pubescent than those collected at lower latitudes. The highest trichome density was observed in the accession collected from the highest latitude $\left(41^{\circ} 11^{\prime} 15^{\prime \prime} \mathrm{N}\right)$ with a trichome density value similar to that of 'Meyer'. It is noticeable that 'Meyer' was more pubescent than 'Zenith' (Table 3). We did not investigate the nanostructures of zoysiagrass leaves in this experiment, such as the ordered patterns of long cells or short cells in leaf epidermal layers and organized layers of cells in the ground tissues of leaves, which do not exist in zoysiagrass as a warm-season $\left(\mathrm{C}_{4}\right)$ grass species (Takahashi et al., 2006).

\section{Leaf epicuticular wax and pigments}

Accessions from lower latitudes $\left(<36^{\circ} \mathrm{N}\right)$, especially Z. pacifica, showed higher leaf epicuticular wax levels than those collected from higher latitudes (Table 4). However, the accessions from low latitudes had poorer low-temperature tolerance compared to the accessions collected from higher

TABLE 4. Leaf epicuticular wax and pigment levels of two commercial cultivars and nine wild accessions of Zoysia spp. Willd. from China prior to and during low temperature dormancy.

\begin{tabular}{|c|c|c|c|c|c|c|c|c|}
\hline \multirow{3}{*}{ Species } & \multirow{3}{*}{$\begin{array}{l}\text { Accession } \\
\text { source }\end{array}$} & \multirow{3}{*}{$\begin{array}{c}\begin{array}{c}\text { Epicuticular } \\
\text { wax }\end{array} \\
\text { Dormancy } \\
\left(\mu \mathrm{g} \mathrm{mm}^{-2}\right)\end{array}$} & \multicolumn{2}{|c|}{ Chlorophyll } & \multicolumn{2}{|c|}{ Carotenoid } & \multicolumn{2}{|c|}{ Total flavonoids } \\
\hline & & & $\begin{array}{c}\text { Prior to } \\
\text { dormancy }\end{array}$ & Dormancy & $\begin{array}{c}\text { Prior to } \\
\text { dormancy }\end{array}$ & Dormancy & $\begin{array}{c}\text { Prior to } \\
\text { dormancy }\end{array}$ & Dormancy \\
\hline & & & \multicolumn{4}{|c|}{$\left(\mathrm{mg} \mathrm{g}^{-1}\right)$} & \multicolumn{2}{|c|}{$\left(\mu g^{-1}\right)$} \\
\hline Z. matrella & Shanghai & $6.4 b$ & $1.58 \mathrm{~d}$ & $0.57 d$ & $1.28 \mathrm{~d}$ & $1.09 d$ & $0.90 \mathrm{c}$ & $1.06 \mathrm{c}$ \\
\hline Z. pacifica ${ }^{\dagger}$ & Jingzhou, Hubei & $10.0 \mathrm{a}$ & $2.57 a$ & $2.20 \mathrm{a}$ & $2.45 a$ & $2.70 \mathrm{a}$ & $1.05 \mathrm{abc}$ & $1.17 c$ \\
\hline Z. japonica & Shanghai & $3.4 \mathrm{c}$ & $2.25 b$ & $0.42 e$ & $2.42 a$ & $0.94 \mathrm{e}$ & $1.04 a b c$ & $1.26 b c$ \\
\hline Z. japonica & Jingzhou, Hubei & $6.6 b$ & $2.11 b c$ & $1.50 \mathrm{~b}$ & $2.43 a$ & $2.15 b$ & $1.03 b c$ & $1.21 \mathrm{c}$ \\
\hline Z. japonica 'Zenith' & U.S.A. & $2.3 d$ & $2.05 \mathrm{c}$ & $0.60 d$ & $1.74 \mathrm{c}$ & $1.14 d$ & 1.14ab & $1.34 b c$ \\
\hline Z. japonica 'Meyer' & U.S.A. & $1.5 \mathrm{e}$ & $0.84 \mathrm{~h}$ & $0.12 \mathrm{~g}$ & $1.30 \mathrm{~d}$ & $0.41 \mathrm{~g}$ & $1.21 \mathrm{ab}$ & $1.30 \mathrm{bc}$ \\
\hline Z. japonica & Shandong & $2.4 d$ & $1.40 \mathrm{de}$ & $0.30 f$ & $2.01 b c$ & $0.55 f$ & $1.07 a b c$ & $1.23 b c$ \\
\hline Z. japonica & Liaoning & $1.9 \mathrm{de}$ & $1.27 e f$ & $0.59 \mathrm{~d}$ & $2.11 b$ & $1.33 \mathrm{c}$ & 1.11ab & $1.38 b$ \\
\hline Z. japonica & Liaoning & $0.2 f$ & $1.07 \mathrm{~g}$ & $0.46 e$ & $1.12 \mathrm{~d}$ & $0.96 e$ & $1.06 \mathrm{abc}$ & $1.31 b c$ \\
\hline Z. japonica & Jilin & $3.0 \mathrm{c}$ & $1.43 \mathrm{de}$ & $0.59 d$ & $1.75 c$ & $0.87 e$ & 1.19ab & $1.54 \mathrm{a}$ \\
\hline Z. japonica & Liaoning & $3.2 \mathrm{c}$ & $1.09 \mathrm{fg}$ & $0.92 \mathrm{c}$ & $1.41 d$ & $1.33 \mathrm{c}$ & $1.22 \mathrm{a}$ & $1.58 \mathrm{a}$ \\
\hline
\end{tabular}

t: also previously known as $Z$. tenuifolia. 
latitudes (Table 2). Therefore, waxy trait should be investigated separately under a warmer climate with respect to drought stress. For example, Awika et al (2017) reported that traits of leaf epicuticular wax and stay-green are associated by a pleiotropic QTL in Sorghum bicolor.

Accessions from lower latitudes $\left(<36^{\circ} \mathrm{N}\right)$ showed higher chlorophyll content prior to dormancy, and this provided corroborative evidence for the greener color of these accessions during that stage. However, because these accessions were more susceptible to low-temperature kill, the advantage of better green color retention is perhaps overweighed by less winter-hardiness. Whether the green color retention is of better value under a warmer climate requires further research. Accessions collected at higher latitudes $\left(>36^{\circ} \mathrm{N}\right)$ showed chlorophyll content higher than that in 'Meyer', but not always higher than 'Zenith' (Table 4). At low-temperature dormancy, leaf carotenoid content in most of the wild accessions from higher latitudes $\left(>36^{\circ} \mathrm{N}\right)$ were higher than that in 'Meyer' but only some were higher than that in 'Zenith' (Table 4). Leaf total flavonoids contents were generally higher in the accessions collected further north than those from south with few exceptions (Table 4). The function of flavonoids in freezing tolerance is popular in plant species as also reported in Arabidopsis thaliana (Schulz et al., 2016) and rhododendrons (Rhododendron L.) (Swiderski et al., 2004).

\section{Correlation between leaf color and leaf structure or pigments}

Leaf stomata density was not correlated with color perception as indicated by the parameters in the CIELAB color space (Table 5). No correlation between stomata density and latitude because of the plasticity of the trait (Petrik et al., 2020). There was a positive correlation between $a^{*}$ value and trichome density $(r=0.34)$ (Table 5), indicating less green perception with higher trichome density. However, there were no correlations between $b^{*}$ and trichome density, or between $L^{*}$ and trichome density, indicating that despite the decreasing green perception with increasing trichome density, the yellow color and brightness during dormancy were not affected. Because leaf trichome density has been widely reported to contribute to thermal stress (Banowetz et al., 2008) and other stress tolerance (Bickford, 2016), it is possible and important to select more pubescent traits without scarifying the appealing dormancy color.

Winter dormancy color matters only if the grass survives. Therefore, when only those accessions and cultivars with a survival rate $>90 \%$ under subzero temperatures were included for calculation, there was a positive correlation between wax levels and leaf brightness $(r=0.46)$ (Table 5). Jefferson (2008) reported that leaf epicuticular wax load and glaucousness in Elymus angustus (Trin.) Pilger are two separate traits. In other words, the contributions of wax load to water conservation and color seem to be separated.
Therefore, it is important to study the genetics of leaf epicuticular wax trait to explore the possibility for improving the brightness of winter dormancy color and winter-hardiness.

A negative correlation between chlorophyll content and $a^{*}$ value was observed $(r=-0.34)$, which is expected because higher chlorophyll content represents greener color and a smaller or more negative $a^{*}$ value (Table 5, Figure 1 ). However, there was a negative correlation between trichome density and chlorophyll degradation as the plants went into low-temperature dormancy $\left(r=-0.36^{*}\right)$ (data not provided in Table). We expect that trichome may serve as a protection against degradation of chlorophyll during the temperature changes and under low-temperature stress, which requires further investigation.

Although leaf carotenoid content was not correlated to any of the parameters in the CIELAB color space (Table 5), the pigment may be responsible for other physiological functions, such as photo-protection (Adams III et al., 2004). The lack of correlation between carotenoid content and yellowish perception $\left(b^{*}\right)$ was perhaps due to the fact that accessions from low latitudes $\left(<36^{\circ} \mathrm{N}\right)$ also had high carotenoid levels despite the poor winter-hardiness (Table 4). If only the cultivars and accessions with $>90 \%$ low-temperature survival were considered, the correlation between yellowish color and $b^{*}$ value was significant $(r=0.37)$.

Total flavonoid content was positively correlated to yellow color as indicated by $b^{*}$ values $(r=0.32)$ (Table 5$)$. This was expected as some pigments in the flavonoid group are responsible for yellow color and traditionally have been used as sources of yellow dyes (Sharif et al., 2020). Flavonoid is a collective name for a group of structures with 15-carbon skeleton consisting of two phenyl rings. Different subgroups and structures of flavonoids have different colors. The final color of leaves or flower petals is a result of multiple flavonoids in different content as well as other pigments and structures. For example, yellow lotus petals contain more flavones and flavonols than anthocyanins (Deng et al., 2013). However, we did not analyze different subgroups of flavonoids in this experiment. Flavonoid types and content change in time with development and growth stages of plants. As a result, leaf and flower colors also change (Davies et al., 1998; Ono and Iwashina, 2015). Besides of the primary existence in vacuoles and cuticular wax, flavonoids also exist in cell walls, making the extraction and study very complicated (Markham et al., 2000). More importantly, since flavonoids also function in plants to combat oxidative stress and serve as growth regulators (Kumar and Pandey, 2013), it is important to further investigate the metabolism and genetics of flavonoids in zoysiagrass. More research is needed to understand the contribution of different subgroups of flavonoids to the dormancy color and physiological functions before it is possible to use this trait to improve both dormancy color perception and winter-hardiness and other stress tolerance.

TABLE 5. Simple correlation coefficients between leaf dormancy color and leaf structure and pigment factors of Zoysia spp. Willd. with two commercial cultivars from the U.S. and 9 accessions from China.

\begin{tabular}{lcccccc}
\hline ICELAB color space & $\begin{array}{c}\text { Adaxil stomata } \\
\text { density }\end{array}$ & $\begin{array}{c}\text { Adaxil trichome } \\
\text { density }\end{array}$ & $\begin{array}{c}\text { Epicuticular } \\
\text { wax level }\end{array}$ & $\begin{array}{c}\text { Chlorophyll } \\
\text { content }\end{array}$ & $\begin{array}{c}\text { Carotenoid } \\
\text { content }\end{array}$ & $\begin{array}{c}\text { Total flavonoids } \\
\text { content }\end{array}$ \\
\hline$a^{*}$ & 0.03 & $0.34^{*}$ & -0.01 & $-0.34^{*}$ & 0.30 & 0.13 \\
$b^{*}$ & -0.27 & 0.25 & -0.25 & -0.14 & 0.24 & $0.32^{*}$ \\
$L^{*}$ & -0.01 & 0.06 & $0.46^{*, \dagger}$ & -0.19 & 0.14 & -0.07 \\
\hline
\end{tabular}

${ }^{\dagger}$ represents two commercial cultivars and 5 accessions that had $>95 \%$ low temperature survival rates in this experiment. 


\section{Conclusion}

Results from this experiment showed that green color retention in zoysiagrass under low temperatures may be associated with lower freezing tolerance due to insensitivity to environmental changes and lack of acclimation. An alternative for keeping aesthetic values is achieving brighter dormancy color which could be contributed from both leaf epicuticular wax and pigments (carotenoids and flavonoids). Significant variations existed in the accessions of zoysiagrass for these traits justifying further investigation. Trichome density showed no effects on dormancy color or brightness. Therefore, selection for more pubescent leaves for stress tolerance should not affect the winter color brightness. Despite the fact that accessions from lower latitudes were waxier, increasing waxiness in winter-hardy materials also increased dormancy color brightness. It is possible to incorporate waxy trait in a breeding program for winter dormancy color of zoysiagrass without scarifying winter-hardiness. Both carotenoid and certain groups of flavonoids contribute to yellow color. Carotenoids also may be responsible for photo-injury protection in fall and winter. Therefore, the metabolism and function of carotenoids need to be further investigated along with the contribution to the dormancy color of zoysiagrass. Similarly, more research is needed on specific yellow groups of flavonoids as well as their genetics and metabolism.

\section{References}

Adams III, W.W., Zarter, C.R., Ebbert, V., and Demmig-Adams, B. (2004). Photoprotective strategies of overwintering evergreens. BioScience 54, 41-49. https://doi.org/10.1641/0006-3568(2004)054[0041:PS OOE]2.0.CO;2.

Airoldi, C.A., Ferria, J., and Glover, B.J. (2019). The cellular and genetic basis of structural colour. Current Opin. Plant Biol. 47, 81-89. https://doi.org/10.1016/j.pbi.2018.10.002.

Akamine, H., Ishimine, Y., Omokawa, H., and Kuramochi, H. (2001). Study on amino acids content in leaf of evergreen type, Mascarenegrass (Zoysia tenuifolia, selected in Utsunomiya University) in winter season. J. Japan. Soc. Turfgrass Sci. 29, 135-137.

Awika, H.O., Hays, D.B., Mullet, J.E., Rooney, W.L., and Weers, B.D. (2017). QTL mapping and loci dissection for leaf epicuticular wax load and canopy temperature depression and their association with QTL for staygreen in Sorghum bicolor under stress. Euphytica 213, 207. https://doi.org/10.1007/s10681-017-1990-5.

Banowetz, G.M., Azevedo, M.D., and Stout, R. (2008). Morphological adaptations of hot sprints panic grass (Dichanthelium lanigunosum var. sericeum (Schmoll.) to thermal stress. J. Therm. Biol. 33, 106116. https://doi.org/10.1016/j.jtherbio.2007.08.006.

Barthlott, W., Mail, M., Bhushan, B., and Koch, K. (2017). Plant surfaces: Structures and functions for biomimetic innovations. NanoMicro Lett. 9, 1-40. https://doi.org/10.1007/s40820-016-0125-1.

Bickford, C.P. (2016). Ecophysiology of leaf trichomes. Funct. Plant Biol. 43, 807-814. https://doi.org/10.1071/FP16095.

Braun, R.C., Fry, J.D., Kennelly, M.M., Bremer, D.J., and Griffin, J.J. (2017). Single and sequential colorant application effects on buffalograss and zoysiagrass color during dormancy. HortTechnology 27, 393398. https://doi.org/10.21273/HORTTECH03690-17.

Brilman, L.A. (2005). Turfgrass breeding in the United States: Public and private, cool and warm season. Intl. Turfgrass Soc. Res. J. 10, 508-514.

Chandra, A., Fry, J.D., Engele, M.C., Genovesi, A.D., Wherley, B.G., Reinert, J.A., Metz, S.P., Zhang, Q., and Okeyo, D. (2015). Registration of 'Chisholm' zoysiagrass. J. Plant Registr. 9, 21-26. https://doi. org/10.3198/jpr2014.04.0020crc.
Chandra, A., Fry, J.D., Genovesi, A.D., Meeks, M., Engelke, M.C., Zhang, W., Okeyo, D., Moss, J.Q., Ervin, E., Xiong, X., Milla-Lewis, S., Brosnan, J.T., Griffin, J., and Parsons, L. (2017). Registration of 'KSUZ 0802' zoysiagrass. J. Plant Registr. 11, 100-106. https://doi.org/10.3198/ jpr2016.03.0010crc.

Christians, N.E., Patton, A.J., and Law, Q.D. (2017). Fundamentals of Turfgrass Management, $5^{\text {th }}$ edn. (Hoboken, N.J., U.S.A.: John Wiley \& Sons, Inc.). https://doi.org/10.1002/9781119308867.

Daly, G.T. (1964). Leaf-surface wax in Poa colensoi. J. Experim. Bot. 15, 160-165. https://doi.org/10.1093/jxb/15.1.160.

Davies, K.M., Bloor, S.J., Spiller, G.B., and Deroles, S.C. (1998). Production of yellow colour in flowers: Redirection of flavonoid biosynthesis in Petunia. Plant J. 13, 259-266. https://doi. org/10.1046/j.1365-313X.1998.00029.x.

Deng, J., Chen, S., Yin, X., Wang, K., Liu, Y., Li, S., and Yang, P. (2013). Systematic qualitative and quantitative assessment of anthocyanins, flavones and flavonols in the petals of 108 lotus (Nelumbo nucifera) cultivars. Food Chem. 139, 307-312. https://doi.org/10.1016/j. foodchem.2013.02.010.

Dunn, J.H. (1999). Low temperature tolerance of zoysiagrasses. HortScience 34, 96-99. https://doi.org/10.21273/HORTSCI.34.1.96.

Ehleringer, J.R., and Bjorkman, O. (1978). Pubescence and leaf spectral characteristics in a desert shrub, Encelia farinose. Oecologia 36, 151-162. https://doi.org/10.1007/BF00349805.

Engelke, M.C., and Murray, J.J. (1989). Zoysiagrass breeding and cultivar development. $6^{\text {th }}$ Intl. Turfgrass Res. Conf., Tokyo, July 31August 5, p. 423-425.

Esteban, R., Fernandez-Marin, B., Olano, J.M., Becerril, J.M., and Garcia-Plazaola, J.I. (2014). Does plant colour matter? Wax accumulation as an indicator of decline in Juniperus thurifera. Tree Physiol. 34, 267-274. https://doi.org/10.1093/treephys/tpu006.

Falk, H. 1989. Chemistry of Linear Oligopyrroles and Bile Pigments. (Vienna, Austria: Springer). https://doi.org/10.1007/978-3-70916938-4.

Fry, J., Kennelly, M., and St. John, R. (2008). Zoysiagrass: Economic and environmental sense in the transition zone. Golf Course Mgt. 76(5), 127-132.

Fukuyama, M., Sato, S., and Kanno, T. (1993). Changes in photosynthetic activity and leaf colour of Japanese lawn grass (Zoysia japonica) during the period preceding dormancy in autumn. J. Japan. Soc. Turfgrass Sci. 21, 179-182.

Gibeault, W.A., Cockerham, S.T., Autio, R., and Ries, S.B. (1997). The enhancement of zoysia winter colour. Intl. Turfgrass Soc. Res. J. 8, 445-453.

Grau, F.V., and Radko, A.M. (1951). 'Meyer' (Z-52) zoysiagrass. USGA J. Turf Mgt. 4, 30-31.

Guimaraes, W.N.R., Martins, L.S.S., Castro, C.E.F., Carvalho Filho, J.L.S., and Loges, V. (2014). Heliconia phenotypic diversity based on qualitative descriptors. Gen. Molec. Res. 12, 3128-3142. https://doi. org/10.4238/2014.April.17.9.

Guo, H., Xuan, J., Liu, J., Zhang, Y., and Zheng, Y. (2012). Association of molecular markers with cold tolerance and green period in zoysiagrass (Zoysia Willd.). Breeding Sci. 62, 320-327. https://doi. org/10.1270/jsbbs.62.320.

Hinton, J.D., Livingston III, D.P., Miller, G.L., Peacock, C.H., and Tuong, T. (2012). Freeze tolerance of nine zoysiagrass cultivars using natural cold acclimation and freeze chambers. HortScience 47, 112115. https://doi.org/10.21273/HORTSCI.47.1.112.

Hortensteiner, S. (2006). Chlorophyll degradation during senescence. Annu. Rev. Plant Biol. 57, 55-77. https://doi.org/10.1146/annurev. arplant.57.032905.105212. 
Hothem, S.D., Marley, K.A., and Larson, R.A. (2003). Photochemistry in Hoagland's nutrient solution. J. Plant Nutr. 26, 845-854. https:// doi.org/10.1081/PLN-120018569.

Hurley, R.H., Yanagi, H., Yamada, T., Sasakura, M., and Tomita, M. (1989). Winter overseeding cool season grasses on dormant zoysiagrass (Zoysia spp.) turfs in Japan. $6^{\text {th }}$ Intl. Turfgrass Res. Conf., Tokyo, July 31-August 5, p. 431-436.

Jefferson, P.G. (2008). Leaf epicuticular wax and glaucousness in Atai wildrye grass: Which trait is most important to water status? Can. J Plant Sci. 88, 447-455. https://doi.org/10.4141/cjps07158.

Kuehni, R.G. (2003). Color Space and its Divisions: Color Order from Antiquity to the Present (Hoboken, NJ, U.S.A.: John Wiley \& Sons, Inc.). https://doi.org/10.1002/0471432261.

Kumar, S., and Pandey, A.K. (2013). Chemistry and biological activities of flavonoids: an overview. The Sci. World J., Dec. 29. https://doi. org/10.1155/2013/162750.

Kuper, R. (2015). Examining the visual effects of plant foliation and vegetative winter dormancy on preference and mystery. Landscape J. 34, 139-159. https://doi.org/10.3368/lj.34.2.139.

Li, C., Wurst, K., Jockusch, S., Gruber, K., Podewitz, M., Liedl, K.R., and Krautler, B. (2016). Chlorophyll-derived yellow phyllobilins of higher plants as medium-responsive chiral photoswitches. Angew. Chem. Int. Ed. 55, 15760-15765. https://doi.org/10.1002/anie.201609481.

Li, M., Li, W., Sun, Y., Mao, P., Qi, X., and Wang, Y. (2018). Analysis of leaf tissue structures between rust-resistant and rust-susceptible Zoysia grass (Zoysia japonica). Acta Phys. Plant. 40, 75. https://doi. org/10.1007/s11738-018-2643-6.

Lichtenthaler, H.K. (1987). Chlorophyll and carotenoids: Pigments of photosynthetic biomembranes. Meth. Enzymol. 148, 331-382. https://doi.org/10.1016/0076-6879(87)48036-1.

Lightner, D.A. (2013). Bilirubin: Jekyll and Hyde Pigment of Life. (Vienna, Austria: Springer). https://doi.org/10.1007/978-3-70911637-1.

Magni, S., Pompeiano, A., and Volterrani, M. (2017). Zoysiagrass use and culture in Europe. Intl. Turfgrass Soc. Res. J. 13, 44-47. https:// doi.org/10.2134/itsrj2016.12.1005

Markham, K.R., Ryan, K.G., Gould, K.S., and Rickards, G.K. (2000). Cell wall sited flavonoids in lisianthus flower petals. Phytochemistry 54, 681-687. https://doi.org/10.1016/S0031-9422(00)00180-1.

Mershon, J.P., Becker, M., and Bickford, C.P. (2015). Linkage between trichome morphology and leaf optical properties in New Zealand alpine Pachycladon (Brassicaceae). N. Z. J. Bot. 53, 175-182. https:// doi.org/10.1080/0028825X.2015.1042486.

Moyroud, E., Wenzel, T., and Middleton, R. (2017). Disorder in convergent floral nanostructures enhances signalling to bees. Nature 550, 469-474. https://doi.org/10.1038/nature24285. https://doi. org/10.1038/nature24285.

Nakamura, N., and Nakamae, H. (1984). Time of flower buds initiation of Zoysia japonica and Z. matrella. J. Japan. Soc. Turfgrass Sci. 13, 117-122.

Ntefidou, M., and Manetas, Y. (1996). Optical properties of hairs during the early stages of leaf development in Platanus orientalis. Austral. J. Plant Physiol. 23, 535-538. https://doi.org/10.1071/ PP9960535.

Okawara, R., and Kaneko, S. (1997). Effect of low growth-temperature on photosynthetic $\mathrm{O}_{2}$ evolution and chlorophyll fluorescence in zoysiagrasses. Grassland Sci. 42, 294-298.

Okeyo, D.O., Fry, J.F., Bremer, D., Rajashekar, C.B., Kennelly, M., Chandra, A., Genovesi, D.A., and Engelke, M.C. (2011). Freezing tolerance and seasonal color of experimental zoysiagrasses. Crop Sci. 51, 2858-2863. https://doi.org/10.2135/cropsci2011.01.0049.
Ono, M., and Iwashina, T. (2015). Quantitative flavonoid variation accompanied by change of flower colors in Edgeworthia chrysantha, Pittosporum tobira and Wisteria floribunda. Nat. Prod. Commun. 10, 413-416. https://doi.org/10.1177/1934578X1501000309.

Patton, A.J., and Reicher, Z.J. (2007). Zoysiagrass species and genotypes differ in their winter injury and freeze tolerance. Crop Sci. 47, 1619-1627. https://doi.org/10.2135/cropsci2006.11.0737.

Patton, A.J., Cunningham, S.M., Volenec, J.J., and Reicher, Z.J. (2007a). Differences in freeze tolerance of zoysiagrasses: I. Role of proteins. Crop Sci. 47, 2162-2169. https://doi.org/10.2135/ cropsci2006.11.0739.

Patton, A.J., Cunningham, S.M., Volenec, J.J., and Reicher, Z.J. (2007b). Differences in freeze tolerance of zoysiagrasses: II. Carbohydrate and proline accumulation. Crop Sci. 47, 2170-2181. https://doi. org/10.2135/cropsci2006.12.0784.

Patton, A.J., Schwartz, B.M., and Kenworth, K.E. (2017). Zoysiagrass (Zoysia spp.) history, utilization, and improvement in the United States: A review. Crop Sci. 57(S1), S-37. https://doi.org/10.2135/ cropsci2017.02.0074.

Petrik, P., Petek, A., Konopkova, A., Bosela, M., Fleischer, P., Frydl, J., and Kurjak, D. (2020). Stomatal and leaf morphology response of European beech (Fagus sylvatica L.) provenances transferred to contrasting climatic conditions. Forests 11, 1359. https://doi. org/10.3390/f11121359.

Pompeiano, A., Caturegli, L., and Volterrani, M. (2011). Freeze tolerance of Zoysia matrella (L.) Merrill as affected by late-season nitrogen application, and changes in carbohydrates during cold acclimation. Plant Biosyst. 145, 885-892. https://doi.org/10.1080/ 11263504.2011.623191.

Pompeiano, A., Grossi, N., Guglielminetti, L., and Volterrani, M. (2014). Winter colour retention and spring green-up of zoysiagrass genotypes in southern Europe. Eur. J. Hortic. Sci. 79, 158-166.

Pompeiano, A., Caturegli, L., Grossi, N., Volterrani, M., and Guglielminetti, L. (2015). Carbohydrate metabolism during wintering period in four zoysiagrass genotypes. Plant Prod. Sci. 18, 43-51. https://doi.org/10.1626/pps.18.43.

Sanchez, F.J., Manzanares, M., de Andres, E.F., Tenorio, J.L., and Ayerbe, L. (2001). Residual transpiration rate, epicuticular wax load and leaf colour of pea plants in drought conditions. Influence on harvest index and canopy temperature. Eur. J. Agron. 15, 57-70. https://doi.org/10.1016/S1161-0301(01)00094-6.

Schulz, E., Tohge, T., Zuther, E., Fernie, A.R., and Hincha, D.K. (2016). Flavonoids are determinants of freezing tolerance and cold acclimation in Arabidopsis thaliana. Sci. Rep. 6, 1-10. https://doi. org/10.1038/srep34027.

Scully, B.T., Nagata, R.T., Cherry, R.H., Nuessly, G.S., Trenholm, L.E., Kenworthy, K.E., Schwartz, B.M., and Unruh, J.B. (2012). Registration of 'Ultimate' zoysiagrass. J. Plant Registr. 6, 71-74. https://doi. org/10.3198/jpr2011.04.0196crc.

Sharif, S., Nabais, P., Melo, M.J., and Oliveira, M.C. (2020). Traditional yellow dyes used in the $21^{\text {st }}$ century in central Iran: The knowledge of master dyers revealed by HPLC-DAD and UHPLC-HRMS/MS. Molecules 25, 908. https://doi.org/10.3390/molecules25040908.

Swiderski, A., Muras, P., and Koloczek, H. (2004). Flavonoid composition in frost-resistant Rhododendron cultivars grown in Poland. Sci. Hortic. 100, 139-151. https://doi.org/10.1016/j. scienta.2003.08.013

Takahashi, Y., Matsuda, Y., Fukuoka, H., and Murata, T. (2006). The morphological characteristics of interspecific hybrids with Zoysia minima and its applications for breeding. J. Japan. Soc. Turfgrass Sci. 34, 96-103. 
Tripathy, A., Goswami, A., and Sen, P. (2014). Single step fabrication of nano-structured superhydrophobic surfaces showing angle dependent colours. IEEE $2^{\text {nd }}$ International Conference on Emerging Electronics (ICEE), Bengalore, p. 1-4. https://doi.org/10.1109/ ICEmElec.2014.7151208.

Turf Producers International (1994). Patten Seed Company of Georgia offering centipede and zoysia seed. TPI Turf News Sept./ Oct., p. 44.

Watson, J.R. (1989). The USGA research committee activities with particular reference to the utilization, problems and perspective of zoysiagrass in the USA. $6^{\text {th }}$ Intl. Turfgrass Res. Conf., Tokyo, July 31August 5, p. 437-440.

Youngner, V.B. (1961). Growth and flowering of zoysia species in response to temperatures, photoperiods, and light intensities. Crop Sci. 1, 91-93. https://doi.org/10.2135/ cropsci1961.0011183X000100020003x.

Received: Dec. 11, 2020

Accepted: Jun. 15, 2021

Addresses of authors:

Lijuan Xie ${ }^{1}$, Huisen $\mathrm{Zhu}^{2}$, Huimin $\mathrm{Guo}^{2}$ and Deying $\mathrm{Li}^{3}$,*

${ }^{1}$ School of Applied Chemistry and Biotechnology, Shenzhen

Polytechnic, Shenzhen, China

${ }^{2}$ College of Grassland Science, Shanxi Agricultural

University, Taigu, Shanxi 030801, China

${ }^{3}$ Department of Plant Sciences, North Dakota State

University, Fargo, ND 58108, U.S.A.

* Corresponding author; E-mail: deying.li@ndsu.edu 
